\title{
Daum's boys
}

Schools and the Republic of Letters in early modern Germany

ALAN S. ROSS

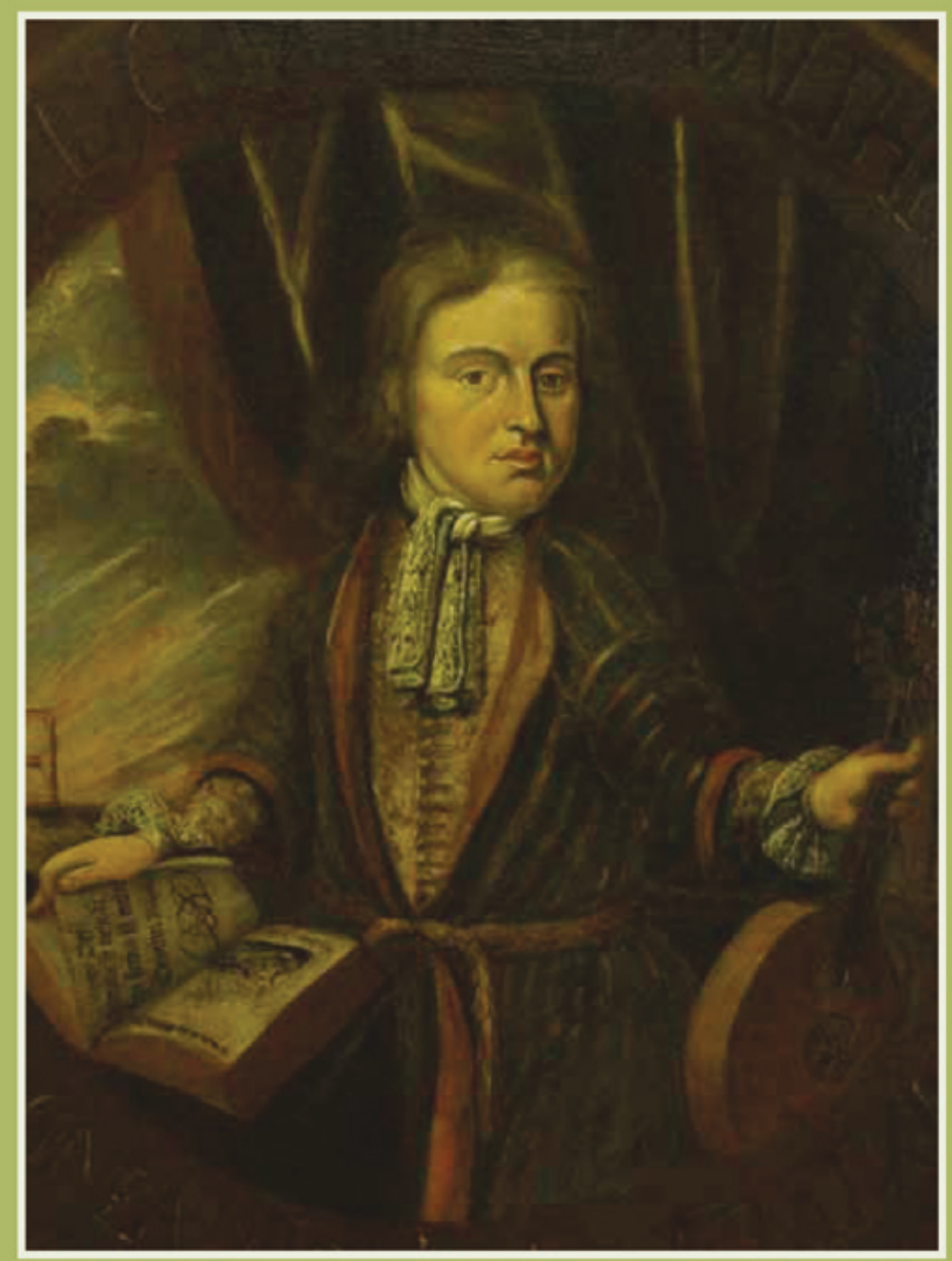


Alan S. Ross - 9781784991708 Downloaded from manchesterhive.com at $04 / 26 / 2023$ ०4:24:31AM via free access 


\section{Daum's boys}

MANCHESTER

1824

Manchester University Press 


\title{
STUDIES IN EARLY MODERN EUROPEAN HISTORY
}

\author{
This series aims to publish \\ challenging and innovative research in all areas \\ of early modern Continental history. \\ The editors are committed to encouraging work \\ that engages with current historiographical \\ debates, adopts an interdisciplinary \\ approach or makes an original contribution \\ to our understanding of the period.
}

\section{SERIES EDITORS}

Joseph Bergin, William G. Naphy, Penny Roberts, Paolo Rossi

Also available in the series

Jews on trial:The papal inquisition in Modena, 1598-1638 Katherine Aron-Beller Sodomy in early modern Europe ed. Tom Betteridge

Princely power in the Dutch Republic: Patronage andWilliam Frederick of Nassau (1613-64)

Geert H. Janssen, trans. J. C. Grayson

Representing the King's splendour: Communication and reception of symbolic forms of power in viceregal

$$
\text { Naples Gabriel Guarino }
$$

The English Republican tradition and eighteenth-century France: Between the ancients and the

$$
\text { moderns Rachel Hammersley }
$$

Power and reputation at the court of Louis XIII:The career of Charles d'Albert, duc de Luynes (1578-1621)

Sharon Kettering

Absolute monarchy on the frontiers: Louis XIV's military occupations of Lorraine and Savoy

$$
\text { Phil McCluskey }
$$

Catholic communities in Protestant states: Britain and the Netherlands c. 1570-1720

ed. Bob Moore, Henk van Nierop, Benjamin Kaplan and Judith Pollman

Orangism in the Dutch Republic in word and image, 1650-1675 Jill Stern

The great favourite:The Duke of Lerma and the court and government of Philip III of Spain, 1598-1621

Patrick Williams

Full details of the series are available at www.manchesteruniversitypress.com. 


\title{
Daum's boys
}

\section{Schools and the Republic of Letters in early modern Germany}

\author{
ALAN S. ROSS
}

Manchester University Press 
Copyright (C) Alan S. Ross 2015

The right of Alan S. Ross to be identified as the author of this work has been asserted by him in accordance with the Copyright, Designs and Patents Act 1988.

Published by Manchester University Press

Altrincham Street, Manchester M1 7JA

www.manchesteruniversitypress.co.uk

British Library Cataloguing-in-Publication Data

A catalogue record for this book is available from the British Library

Library of Congress Cataloging-in-Publication Data applied for

ISBN 9780719090899 hardback

First published 2015

The publisher has no responsibility for the persistence or accuracy of URLs for any external or third-party internet websites referred to in this book, and does not guarantee that any content on such websites is, or will remain, accurate or appropriate.

Typeset by Out of House Publishing

Printed in Great Britain

by TJ International Ltd, Padstow 